\title{
Travel Philanthropy in the Larabanga- Mognori Tourist Enclave in Northern Ghana
}

\author{
Conrad-J.Wuleka Kuuder \\ (Corresponding Author) \\ Department of Ecotourism and Environmental Management \\ University for Development Studies, Ghana \\ kwuleka@uds.edu.gh \\ Whitney Sunkwah Yeboah \\ Department of Ecotourism and Environmental Management \\ University for Development Studies, Ghana \\ Evelyn K. Yirbekyaa \\ Department of Basic Education, University for Development Studies, Ghana \\ Getrude Poku \\ Department of Ecotourism and Environmental Management \\ University for Development Studies, Ghana \\ Catherine Fosulade Arowosafe \\ Department of Ecotourism and Wildlife Management, \\ Federal University of Technology, Akure, Nigeria

\section{Chrysogonus Anab} \\ Department of Development Education, University for Development Studies, Ghana

\section{Ernest Bagson} \\ Department of Governance and Development Management, \\ University for Development Studies, Ghana \\ DOI//http://dx.doi.org/10.4314/gjds.v16i3.4
}

\section{ABSTRACT}

Travel philanthropy is a growing phenomenon within the Larabanga-Mognori enclave in northern Ghana. This article seeks to assess the impacts of such visitor largess on community needs and development. Purposive sampling techniques were employed in 
selecting some respondents namely tour guides (in Larabanga) and cultural dancers (in Mognori) using focus group discussions (FGD) as a tool in eliciting data. A number of household heads were reached in both communities for their responses through in-depth interview (IDI) schedules. Data sourced which were mainly qualitatively was analysed in thematic frames. The study revealed that through visitor largess, amenities like boreholes and schools had been provided both communities. Other basic needs such as clothes, shoes, stationery and backpacks for school going children were also donated by tourists in both communities whilst instances of cash donations to some individuals were also reported. Both communities benefited from a donation of school blocks from visitors. The study concludes that adherence to personal hygiene and sanitation practices implied an improvement in living standards afforded through their encounter with tourists. Community members and elders are encouraged to put documented measures in place so that visitor philanthropy can be accounted for and be firmly rooted in the communities.

Keywords: Travel Philanthropy, Largess, Donations, Tourism, Knowledge Transfer

\section{INTRODUCTION}

Tourism is undoubtedly one of the most essential phenomena shaping our world (Cohen \& Kennedy, 200o). It is also economically recognised as of growing importance to many countries, as it is the largest export earner of foreign exchange and employment in the world (WTO, 1999). The phenomena create a linkage between the relatively wealthy, in time and money with the less wealthy. This invariably means that, the wealthy can also visit places that are noted to be relatively poor, in order to explore different cultures and have the opportunity to contribute to the development of such destinations. Most visitors visiting poor destinations are from origins with high or upper-center wages. This perception adds to the idea that tourism is the biggest willful exchange of assets from the rich to the poor (Mitchell \& Ashley, 2010). It is through this that travel philanthropists have made impacts and improvement of livelihoods in designated communities. Past studies have shown that the practice of giving in its various forms has remained firmly embedded in human exchange (Ayeetey \& Opai-Tetteh, 2012).

Travel philanthropy or visitor largess refers to donations of money, in-kind resources or time facilitated by people on tour (Goodwin, McCombes \& Eckardt, 2009). Travel philanthropy has also been efficient in giving developmental assistance such as funds, labour and other resources that flow directly from the tourism industry into community development and environmental initiatives. The donations can be undesignated such as new or used goods and services including clothing, toys, food and vehicles offered independently. They can also be designated 
such as cash made by affiliated organisations. Tourists giving donations such as time and money could be the main purpose of the tourism experience or it could also be an incidental consequence of travelling to disadvantages places affected by poverty, environmental problems and some diseases (Novelli, 2015). Travellers and tourism companies have been making donations of cash and kind for years. Examples of such visitor largesse have been noted in the literature as in for instance, in Cuba, where Havana's first English Language bookstore, (Cuba Libro), coordinated donations of books made by tourists to local school children in 2016 and 2017 (Culture Trip, 2019). Again and in line with the above, there is an Alms Ceremony that is held each year in Luang Prabang Province in Laos, where it was recorded in December 2007 that $90 \%$ of the people giving alms were tourists themselves (Nepal Almsgiving Ceremony, 2019).

In Africa, a clear case of using proceeds from tourism and sourcing donations to develop local communities is noted in Masai Mara communities located in Kenya. Known as the Governors Camp Project, the project has been able to source donations from visitors and the proceeds used in supporting two local schools and the clinic in Mfangino Island. At the local primary school for instance, classrooms have been equipped with desks and blackboards whilst text and exercise books were supplied to two classes. Logistical support has also been offered to a contractor to build more classrooms and a toilet facility (Governors Camp, 2019).

In Ghana, the Daily Graphic Newspaper of Thursday, September $23^{\text {rd }}$, 2010 disclosed that, due to the visibility of the Mognori Eco village in tourism development, there has been support for social developments in that local community. One of such is the primary school in the local community which has received many donations from tourists with some volunteering to teach in schools (Porekuu, 2010:19). This study therefore seeks to uncover how visitor largess impacts on community development especially taking a cursory look at the Larabanga-Mognori Ecovillage tourism enclave. This tourism enclave with its various smaller other attractions, is usually a "must visit" for visitors who come to the most popular national park for game viewing in Ghana.

Research has shown that corrupt institutions and inadequate capacity building are some of the causes that have led to the failure of travel philanthropy being successful (Nelson \& Agarwal, 2008). Indeed, leaders in the tourism industry are now rather interested in harnessing tourism's opportunities for their own private wealth accumulation benefits and thus commandeer scarce communal resources for their own purposes to the neglect of the larger society (Higgins-Desbiolles, 2006). As a result, tourism's full potential is squandered and its promise of many humanitarian benefits for humanity sake remains unfilled, thereby defeating the 
purpose and intent of travel philanthropy (Higgins-Desbiolles, 2006). This leads to the issue where the purpose of the donations by the tourists will not be used for the intended common good of the local people in the destinations. It is still not precisely known how donations made by tourists are channeled into the development of the destinations particularly in countries where institutional and petty corruption seems endemic.

Most destinations also keep no records of such philanthropic support and very few have systems in place to be able to easily report how much is raised by local destination enterprises, staff and even travellers (Goodwin et al., 2009). This consequently gives a leeway to the mismanagement of the funds and contributions made by travellers to the communities.Travel philanthropy are largely unstructured and informal in Ghana though giving is common. This makes it difficult to mobilise funds for planned social development since data on this kind of giving is virtually inexistent (Ayeetey \& Opai-Tetteh, 2012). It is in the light of the above that this study is relevant, especially making attempts at ascertaining whether such donations really go to the needy in the community or is it the case that it is usually hijacked by a "cabal system" in the community; as often is the case in most community-based tourism projects?

Giving in disadvantaged destinations can be extremely convoluted as they are utilised for different purposes. Due to poor administration of gifts, absence of responsibility and correspondence, the demonstration of giving is risky (Mohamadou \& Hathie, 2015). The main challenge for travel philanthropy is to exploit on, yet differentiate itself from, traditional philanthropic methods based on short-term, project-specific charitable donations, which tend to deliver uneven results (Ashley \& Haysom, 2006). According to Wood (2015), well-intended people who truly want to make a difference simply do not know where to begin or whether their efforts will really have an impact. When able to execute philanthropy, most visitors unfortunately are not able to follow up on the donations made at the destination when they return home because most tourism destinations do not have well developed systems for them to do so (Elevate Destinations, 2012).

In the same light, contributions are not predictable and sustained over time. Donations such as used clothing for example lead to dependency on outside support (another criticism) rather than helping to build capacity and strengthen local empowerment and self-sufficiency. In most cases, one-time contributions by visitors cannot help to bring about fundamental changes unless they become part of a pool of funds dedicated to meaningful development projects (Spalding, 2011). 
This paper seeks to assess the impacts of visitor kindness on community development in the Larabanga-Mognori enclave, while seeking specifically to identify the forms of donations made by visitors; and furthermore, examine if such philanthropy has translated into the community's developmental needs. The study thus seeks to contribute to the unfolding critical literature and recent deliberations on the efficacy of such charitable gestures and how such gestures contribute to outcomes in receiving destinations particularly in rural settings. The study again will contribute to knowledge in what is often known in tourism literature parlance as social justice tourism (Higgins-Desbiolles, 2008).

\section{METHODOLOGY}

\section{Study Area}

Mognori and Larabanga are communities located in the West Gonja District of the Savannah Region of Ghana. The Savannah Region is located to the east of Tamale. The district (West Gonja) has a total land area of $4715.9 \mathrm{sqkm}$, parts of which are occupied by Mole National Park and Kenikeni Forest Reserve. The total population of the district (West Gonja) is 41,180 and the vegetation of the area falls within the Guinea Savanna ecological zone (GSS, PHC, 2010).

\section{Profile of Mognori Eco-village}

Mognori is a farming community, relatively close to the south-eastern border of Mole National Park. Mognori which translates into 'river bank' was coined from the proximity of the community to the White Volta. It is $15 \mathrm{~km}$ from the park headquarters and about 20km from Larabanga in West Gonja District (Kuuder, Bagson, \& Aalangdong, 2013). The inhabitants of this community are mainly farmers and to a lesser extent, fishermen due to its proximity to the river (Mohamadou \& Haithi, 2015). Mognori Ecovillage was essentially created about twelve years ago to offer the local community a chance to get involved in tourism activities using Mole National Park as an attraction and to garner revenue proceeds to develop the village and better their lives. It is on record that 1,571 tourists visited Mognori Ecovillage in 2017, earning the community-based attraction generated revenue of GH 23, 096, as reported by The Business and Financial Times (2018).

\section{Profile of Larabanga}

Larabanga is a community with a population of about 4000 residents with the majority being Muslims. A native of Larabanga is known as a Kamara. The main occupations of the inhabitants are farming and hunting (Apawu, 2012).Within the Larabanga community is located the famous Larabanga Mosque which is said to be 
the oldest in Ghana. The mosque is believed to have been built by Moorish traders during the trans-Saharan trade era in the 13th century. It is also believed that the mosque was originally founded in 1421 (Apawu, 2012) and arrivals therein recorded 864 tourists in 2017, generating GH\$4, 320 to the community (The Business and Financial Times, 2018).

\section{Research Approach}

Qualitative research strategies were opted for to enable indigenes with institutional knowledge (tour guides in Larabanga and Cultural dancers in Mognori) in addition to selected heads of households give narratives of their lived experiences with respect to philanthropic travellers' contributions to community development. The qualitative approach has been opted for in order to understand respondents' views and perceptions by observing gestures, postures and body language and studying these to diagnose the real issues behind problems emanating.

\section{Sample Size Determination}

During a reconnaissance visit to the research locations, lead persons (a tour guide designated by the tourism committee of the community) to help the study team do a nominal count of household heads in each community (Table 1). 10 heads of households, as key informants, from Mognori community were interacted with and this represented 15 percent of the total heads of households who willingly accepted to participate in the study seen as representative enough of the community's viewpoint on philanthropic travellers' contributions to community development. Similarly, 50 heads of households were also selected from Larabanga (with the help of the guide) and this represented about 10 percent of the total number of household heads which was also deemed an adequate representation. A total of 60 heads of households were involved in the study (see Table 1).

Table 1: Sample size for IDIs

\begin{tabular}{|l|l|l|}
\hline Community & Number of Households & Number Selected \\
\hline Mognori & 57 & 10 \\
\hline Larabanga & 500 & 50 \\
\hline Total & 557 & 60 \\
\hline
\end{tabular}

Source: Field Data, 2019

For FGDs, the Mognori community had a total of 21 dance troupe members from which a 12 member group comprising 7 male and 5 female was organised based on availability were held. The Larabanga area had a total of 20 trained tour guides from which an all-male 12 member group available was organised to participate. 


\section{Research Instrumentation and Data Analysis}

Techniques adopted by the research team to obtain data from locales in the community who held relevant information on ongoing tourism-related activities included the following: The designated guide who was tasked in each community led the research team to households deemed to hold relevant information on issues pertaining to travel charity. Some local people interviewed were those directly in charge of development related concerns within both communities namely the chief, an elder and the assemblymen of the two electoral areas in the study community. An interview guide was developed and used to carry out IDI with heads of households in both communities. Similarly, a FGD guide was developed to enable the research team elicit information from respondents on donations made in their community. The sequential use of the 2 data collection guides enabled quality check on the field data. The questions were open ended to allow a wide range of answers from respondents.

Data was analysed manually using the coding and thematic analytical processes. Coding in qualitative analysis refers to finding a phrase or labelling sections of a text to represent similar ideas that will come up within the data set. Themes were developed to categorise or put several codes with similar ideas together. This was done using highlighters. A thematic network was then used to join two or more themes that talked about the same thing/issue into one broad theme for analysis of findings in the data set according to Attride-Stirling (2001) analytical frames.

\section{RESULTS AND DISCUSSION}

The results garnered centred on the forms of various philanthropic donations made by tourists to Mognori and Larabanga communities and have been grouped into sub-themes. The analysis also revealed responses on how donations have led to community development and how these have enhanced their living standards.

\section{Forms of Philanthropic Donations}

The forms of philanthropic donations within the Larabanga-Mognori enclave have been presented in sub-themes. These different forms of donations have been grouped into "thematic forms, the first being: In kind donations, monetary donations, education and training donation, while the second group are from individuals and Non-governmental organizations (NGOs). Officials from the NGOs came on tour and also used the opportunity to do charity work. 


\section{Thematic Forms (Education-Related Donations in Larabanga Community)}

The donations made in order to promote educational ventures in the community came mainly in the form of stationery such as books, pens and pencils. These pieces of stationery, donated by some tourists, to the schools in the community catered for the needs of the pupils as some parents were unable to afford. This finding was expressed by five household heads (all parents). According to the respondents, these donations helped to reduce the additional cost burden of sending their children to school after paying fees. The revelation was made as follows:

Yes, tourists do come on visits, make donations to the schools but not so often. Our kids come back from school and show us the exercise books, pens and pencils they received from tourists. They sometimes come back with story books containing colourful pictures which helps improve their reading skills. These donations are very helpful because the cost of acquiring these materials for our children are lifted off our heads and we believe if such gestures continue, it will help our kids to become better scholars.

The above response relates with the literature whereby it is stated in Cuba that, Havana's first English book store, Cuba Libro, had books donated by tourists to the local school children in 2016 and 2017 as reported by Culture Trip (2019). This is another advancement made in travel philanthropy to promote education in remote communities and has helped children who cannot afford formal education to acquire some level of education.

It was again reported by guides during the FGD session that two tourists visited the community and built a local school for them. This was affirmed as follows:

Two tourists visited the community in 2004 and after tour of the mosque and spending a few days in the community, mobilised funds from home and built a school for the community. Every community in Ghana now is aware of the developmental opportunities associated with formal schooling and we appreciate the gesture of the visitors. The name of the school is Banbaninye Primary School and it was completed on the $3^{\text {rd }}$ of February, 2005.

This show of benevolence in Larabanga whereby two tourists decided to help build a 3-unit primary school block for the community is a community developmental need appreciated by residents in Larabanga espoused in the aforementioned reportage. This scenario is equally similar to a development cited by Kuuder and Adongo (2012), in which they reported of Ms Mora Lechman, a student of University of Social Work 
in Switzerland, who came visiting Bofourkrom as a tourist in 2002, went back home, solicited funds and helped construct a 6-unit school block in Bofourkrom. Figure 1 shows a 3-unit classroom block built through such philanthropic gesture in Larabanga in 2002.

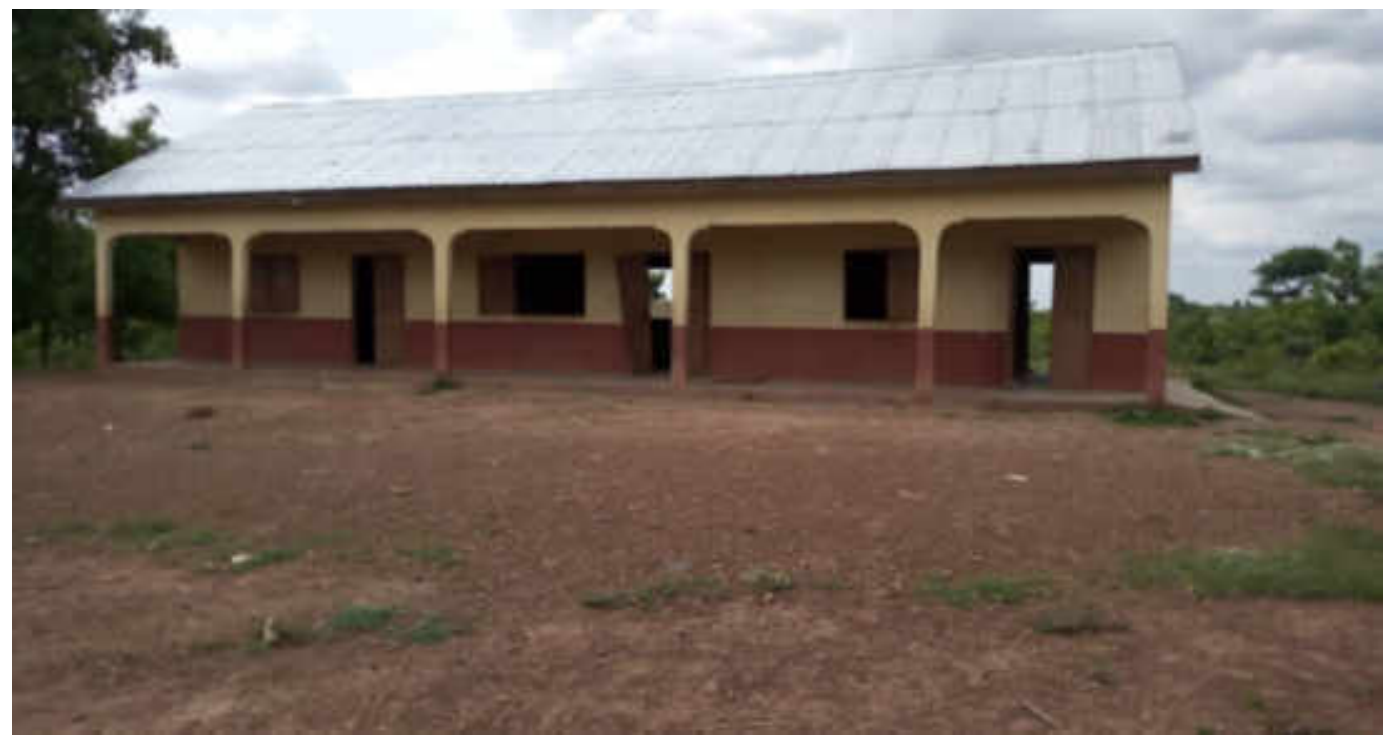

Figure 1: Banbaninye primary school in Larabanga

Source: Field Data, 2019

\section{Thematic Forms (Education Related Donations in Mognori Community)}

Donations made to Mognori community in lieu of promoting education came in the form of stationery (books, pens and pencils). Other materials such as school bags (backpacks), footballs and uniforms were also donated by tourists in the past. Four respondents disclosed this:

It was helpful when donations such as books, pens, pencils, bags and uniforms were frequently gifted us about three years ago but now it isn't so. Now tourists come to spend some days in the community and just leave. Their largess is reducing in recent times. We are therefore not expectant of anything but focus on getting these materials for our wards for school.

The above reportage by respondents confirms a reportage by Porekuu (2010) who disclosed that, due to the visibility of the Mognori Ecovillage in tourism development, one beneficiary is the only primary school in the community which had received many donations from tourists, notably stationary, jerseys, footballs 
and other teaching and learning equipment while some visitors volunteered to teach in the local school.

A discussant among the dance troupe members revealed that tourists sometimes donate jerseys, aside from footballs to the pupils for co-curricular sessions:

The children never got engaged in any co-curricular activity before. A tourist came and noticed this and on his next visit to the community he brought footballs and jerseys. The children can now engage in games on Saturdays or after school when they have nothing else to do.

This finding seems to exemplify similar sentiments expressed by Novelli (2015), who indicated that travel philanthropy is seen first as a means of development and secondly as an act of benevolence flowing from travel industries and tourists into community projects thereby depicting the largess brought in by the tourism industry. An opportunity in developing sports in the basic school poses two developmental dimensions: The career development related benefits and health (physical activity) related benefits afforded through such sports equipment donations. Thus, both Larabanga and Mognori communities received donations which were intended to promote basic education in their communities.

\section{Source Forms (Monetary Donations in Larabanga Community)}

Monetary donations also came in from tourists to the community but on rare basis. Such monies were given to the elders and the information only existed as rumours as the disclosures never came from the elders. Five respondents during separate IDIs revealed as follows:

Sometimes we hear of the elders receiving money from visitors to help the community but we have never personally received any money from the elders nor has there ever been a community durbar where records of such monetary donations have been made to us. Announcements have however been made before that money has been given to the community to embark on projects but evidence of such projects are yet to come to fruition.

In Larabanga, as contained in the aforementioned finding, funds accordingly came in as donations to the community through the elders but some respondents complained they have never known what such donations were used for in the community. Criticisms such as these are further explained by Higgins-Desbiolles (2006), where he disclosed that tourism's full potential is squandered when some leaders in the community are rather interested in harnessing tourism opportunities 
for their own private wealth accumulation and gain either than using it for the common good of the local people.

Two (2) tour guides during the FGD session, confirmed tourists did donate money to elders and the tourism office for community development although seldom. They asserted as follows:

When the tourists come, they donate money to the community through the tourism office. The elders then meet and discuss what the money should be used for in terms of purposes of community development but so far nothing has been done to show what such monies are used for. No records are kept for donations made and this makes it hard to know the amount of money donated.

This reportage poses a worrisome development, as funds meant for community development are allegedly diverted into private pockets thus stifling communal advancements. This finding which indicates that no records of monetary donations are kept by the communities confirms similar finding by Goodwin et al. (2009) who in their research revealed that community leaders did not keep records of donations made by visitors at the tourist destination areas and this made it difficult to track such resources and what they were intended for.

\section{Source Forms (Monetary Donations in Mognori Community)}

In Mognori, monetary donations made were infrequent and equally not given to elders as was the case in Larabanga. Some individuals however revealed locales benefited from the benevolence of some tourists. Some household heads revealed as follows:

Visitors sometimes give us money as they walk through the community and interact with us. Such monies are not much but we appreciate it all the same. Such monies help us to acquire some of our basic needs.

This finding here is in tandem with a research done by Honey (2011) in which it was revealed that individuals represented the largest source of philanthropic donations when on tour. This sentiment of Honey (2011) reflects in the two study communities as respondents commented that a greater chunk of donations to them came from individual tourists while less came from associations or group tourists.

Revelations again were that, no records were kept on donations in the community and it was therefore difficult to ascertain the amounts received. Two male dancers during the FGD session disclosed as follows: 
There is no book kept in the community that we use to record monetary donations as they are made and because of this we do not know the actual monies received within a month or a year. It is also difficult to quantify the total amount of monies received because indigenes received these in private.

\section{Thematic Forms (Incidence of Knowledge Transfer in the Larabanga Community)}

Tourists relayed their knowhow on soap making, personal hygiene and sanitation related matters in the community. Local soap making skills imparted by tourists to women has also been 'imbibed' as expressed in the IDI responses:

Some tourists taught our children English in our schools while some during their stay helped impart knowledge to the women on how to make local soap. We use this local soap for domestic purposes and most of the women have picked it up as a business and are now earning income.

In Larabanga, it was mostly women who were engaged in soap making as noted in the findings. Helping indigenes find alternative livelihoods with the advantage of offering them a source of income is an important developmental intervention aimed at improving living standards in the study community. The finding is thus in line with a similar gesture by the Grootbos Foundation, established in 2005 revealed by Goodwin et al. (2009) who indicated in the literature that the foundation encourages tourists visiting the Grootbos Nature Reserve to donate funds on-line. Their aim was to empower women in Masakhane Township (South Africa) by teaching them skills needed for cloth painting, beadwork and sewing for a livelihood.

Community members were 'enlightened' on how to keep their environment clean, improve general sanitation and with lesson tips on personal hygiene notably no-littering and regular hand washing with soap under running water. In an IDI session, two heads of households expressed their views thus:

We have been conscientised by tourists on how to keep our environment clean through using dustbins for waste disposal. We were also taught the importance of washing our hands with soap under running water as the most effective way of removing dirt form our hands. Tourists educated us to put a stop to littering the environment which can promote the spread of diseases.

Tourists who stayed in the community for a week or more also benefited from knowledge transfer. This report from a respondent confirms this stance: 
The visitors also took the opportunity to learn and pick a few words from our native local language (Gonja) and the women teach some of them how to process sheabutter which is of great interest to them.

There were instances of tourists volunteering to teach English and other subjects in both study communities and this gesture helps to augment the poor staffing situations noted in the basic schools in the two communities. These revelations exemplify the literature noted by Beary (2008), who indicated that individuals and groups who went on a five-day tour of the Pang Soong Nature Trail Project in Thailand in October 2006, volunteered to work as assistants in local schools and taught English.

\section{Thematic Forms (Incidence of Knowledge Transfer in the Mognori Community)}

The main knowledge/skills transfers that occurred in Mognori were in bee keeping, personal hygiene and sanitation including volunteer works like teaching students in schools. Farmers therefore had an alternative source of income. A male head of household shared his view on bee farming in the ensuing revelation:

Some tourists visited the community a few years ago and during their stay shared skills in bee farming with us. We learned skills in beehive construction and bee attraction. A lot of men in the community are now into bee keeping because income from harvesting honey is good.

Tourists conscientised the local people also in the area of sanitation and personal hygiene aimed at improving general health and sanitation in the community. Two household heads shared their views as follows:

Tourists did help raise awareness on the need for good sanitation practices and encouraged us to wash our hands with soap under running water. They also taught us proper waste disposal encouraging us to do burning and likewise making use of waste bins.

Tourists volunteered to teach students in the community school. A female dancer during the FGD sessions brought this to light and her views were corroborated by colleagues as follows: "Tourists who stay in the community for more than two days often volunteer to teach students in the local school and this gives them exposure to different teaching methods."

This finding is similar to the literature as noted by Beary (2008), where individuals on a five-day tour of the Pang Soong Nature Trail Project in Thailand in October 2006, volunteered to work as assistants in local schools by teaching English. 


\section{Source Forms (Donations by NGOs to the Larabanga Community)}

Staff of Non-governmental organizations (NGOs) came on tour and did take opportunity to make donations to fringe communities of Mole National Park (Larabanga inclusive). This was reported by two household heads and their views were recounted as follows:

NGOs such as World Vision International (WVI) and Campaign for Female Education (CAMFED-Ghana) came and donated stationery (books, pens and pencils) to our children in school. They usually do this after taking a tour of our attractions in the community. Scholarships have also been awarded our girls whereby their school fees are paid in full.

These NGOs also drilled a borehole and further donated clothes and money to the orphanage in the community. A household head brought the following to light: "CAMFED-Ghana and WVI donated money and clothes to the orphanage. WVI also drilled a borehole in the community. These gestures have helped in the running of the facility and this also ensures that inmates are well catered for."

This show of largesse by staff of CAMFED-Ghana and WVI-Ghana after making a tour of their attractions portray a similar philosophy revealed by Macy (2011), who stated that NGOs and sympathetic visitors made cash donations including books and clothing when they visited the orphanages in Bali. Similarly, in Larabanga, visitors also extended help to the community orphanage, through teaching English and donation of assorted items to the facility. This seems to exemplify the findings of WTO (2004), which revealed that a local NGO called Ptea Teuk Dong in Cambodia used a percentage of revenues from each trip at the MAD Adventures, an independent adventure tour operator to improve the lives of street families in Battambang Province in that country. Helping the destitute and vulnerable in the Larabanga community find shelter, food and also to seek education is an important developmental agenda that can rid the community of future liabilities.

\section{Source Forms (Donations by NGOs to the Mognori Community)}

The Netherlands Development Organisation (SNV) from the onset was involved in the community sensitization to help kick start the tourism project and enable it gain its feet. Mognori community has received donations from NGOs and among such donations are construction of latrines, granting of scholarships, drilling of boreholes among others. Discussants during FGD session revealed the following:

SNV helped to construct latrines for the community a few years ago and this has helped to curb problems associated with open defecation (OD) which was a problem years earlier. They used their own resources to 
undertake the latrine project construction while the community supplied labour.

See Figure 2 on latrine and tippy tap facility in Mognori Community

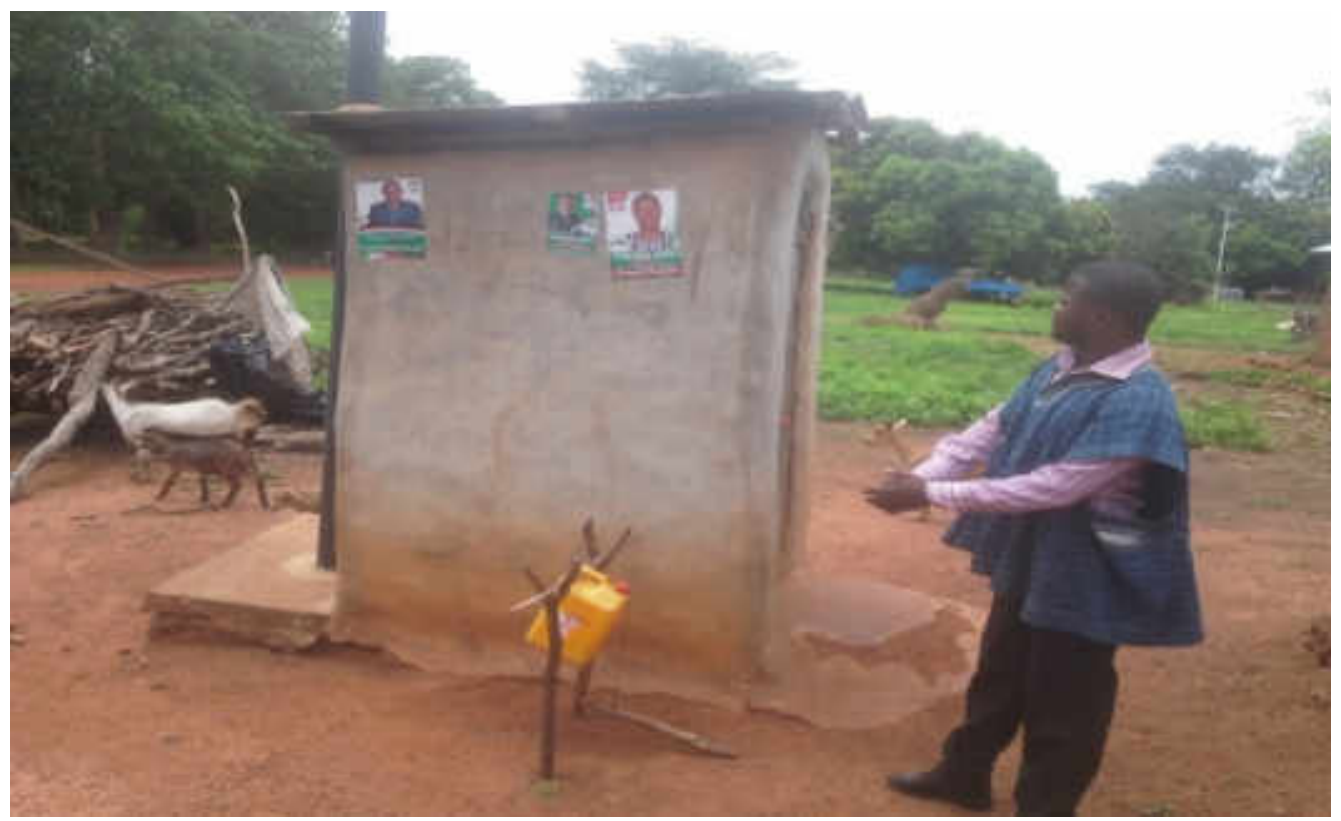

Figure 2: Pit latrine and tippy tap facility in Mognori Community

Source: Field Data, 2019

An NGO also provided scholarship opportunities to children in the community as disclosed by a FGD participant: "WVI-Ghana has awarded scholarships to some children in the community and this has provided opportunities for brilliant but needy students to access formal education."

Boreholes in the community were reportedly also drilled and constructed by NGOs as revealed in the survey and for years, these served as the most convenient sources of potable water for the community members. The ensuing revelation explains this better: "The boreholes in the community have given us a reliable source of potable water. Before this, our only source of water was the river which was not healthy for human consumption."

A male head of household also mentioned an NGO whose leadership came on tour to the community and later went back to Accra to mobilise resources to help construct a nursery school in the community. He explains:

In 2017, an organization called Student Youth Travel Organisation (SYTO) came to our aid with financial resources to build a nursery for the 
pre-school children in the community. This has helped many kids access pre-school education in the community.

It was revealed that it was not the case that philanthropy only came from the visitors. The local people always showed same in a reciprocal gesture: "We also show these visitors kindness anytime we obtain something of value from them. In the case of the NGO officials who brought us this nursery block project, in return we gave them smocks, woven cloths and calabashes of shea butter as a show of appreciation."

From the results which is indicative of SNV helping to construct latrines including aiding in the construction of tippy taps, WVI-Ghana providing scholarships to school children, NGOs helping provide potable water and the kindness shown by SYTO through the construction and equipping of a nursery block in the Mognori area and CAMFED-Ghana and WVI-Ghana providing scholarships in Larabanga are noted gestures that are development oriented. Provision of potable water and aiding the locales to put an end to open defecation are noted indicators of improved living standards. Such gestures are also linked to the literature espoused by Goodwin et al. (2009) who made assertions of travel philanthropy being an umbrella of corporate or potentially close to home philanthropy. These findings again are in line with the research done by Mohamadou and Hathie (2015) which identified forms of philanthropic donations common to West Africa one such categorization being corporate philanthropy.

\section{CONCLUSION}

The Larabanga Mognori tourist enclave has benefited from the largesse of visitors in the form of donations. Although travel philanthropy is purportedly infrequent in the area, it has contributed a fair bit to the development of these communities. Mognori Community has benefited from provision of a Pre-School block while Larabanga also benefited from the donation of a three-unit classroom block. There is the potential for community members to continue to benefit from holiday seekers who come to a major attraction in the area (Mole National Park) and also take opportunity to visit smaller attractions in the study communities. Generally, all the respondents asserted to philanthropy being an on-going phenomenon in both communities and is mostly dependent on the length of stay of the tourist. Donations were confirmed to be done at the free will of the tourists. The forms of philanthropic donations were identified to be mostly education related such as stationery, books pens, money and other in-kind donations like used clothes and shoes. 
Other donations were made by NGOs; and these came in the form of provision of boreholes and latrines which are noted benchmarks of improved living standards. Knowledge or skills transfer from tourists reflected in community members benefiting in new trades (soap making) availing women in Larabanga an alternative source of income aside from their farming activities. They also benefited from sanitation related lessons (regular hands washing with soap using the tippy taps in Mognori). All these gestures have in one way or the other improved their living standards. Lack of record keeping and no proper accountability done for donations made during community meetings were some of the constraints bedevilling travel philanthropy in the communities.

\section{RECOMMENDATIONS}

Based on the findings of this research and the concerns raised by respondents, the following recommendations were made:

- Proper records of all donations should be kept to help quantify the amount of donations made within the year. This can be relevant for development purposes as such records can be tracked to enable them get a better picture showing how helpful philanthropy is.

- Well-developed systems should be created to allow visitors to follow up on donations made.

- Livelihood related skills transfer from tourists to community members should be encouraged on group basis, so that groups will amass common capital, monetary or non-monetary, to sustain their businesses to derive collective benefits.

\section{REFERENCES}

Apawu, J.K. (2012). Senses and local environment: The case of Larabanga in the Northern Region of Ghana. Doctoral dissertation submitted to University of Ottawa, Canada.

Aryeetey, E.B. and Opai-Tetteh, D.D. (2012). The art of giving-through volunteerism and philanthropy (Online). Available at: http://ugspace.ug.edu.gh/handle /123456 789/21965. Accessed 24 ${ }^{\text {th }}$ May, 2019.

Ashley, C. and Haysom, G. (2006). From philanthropy to a different way of doing business: Strategies and challenges in integrating pro-poor approaches into tourism business. Development Southern Africa, 23(2), pp. 265-28o.

Attride-Stirling, J. (2001). Thematic networks: an analytic tool for qualitative research. Qualitative research, 1(3), pp. 385-405. 
Beary, S.K. (2008). Voluntourists without borders. (Online). Available at: http://www. voluntourists-withoutborders.com/html. Accessed $24^{\text {th }}$ June, 2018,

Cohen, R. and Kennedy, P. (2000). Global sociology. Hounds mills, Basingstoke, UK: Macmillan Press.

Culture Trip (2019). Cuba Libro: Welcome to Havana's most unique bookstore. (Online). Available at: https://heculturetrip.com/caribbean/cuba/articles/cuba-librowelcome-to-havanas-most-unique-bookstore/. Accessed $1^{\text {st }}$ August 2019.

Elevate Destinations (2012, June 13). What is travel philanthropy? (Online). Available at: https://www.huffpost.com/entry/what-is-travel-philanthro_b_1405994. Accessed 20 ${ }^{\text {th }}$ June, 2019.

Ghana. Statistical Service. (2014). 2010 population and housing census report. Accra, Ghana Statistical Service.

Goodwin, H., McCombes, L. and Eckardt, C. (2009). Advances in travel philanthropy: Raising money through the travel and tourism industry for charitable purposes. WTM Responsible Tourism Day (Report 2). (Online). Available at: www. icrtourism. org/documents/2_nov_wtm_tp_final_report.pdf. Accessed $10^{\text {th }}$ November, 2018.

Governors Camp (2019). Community and conservation. (Online). Available at: https:// www.governorscamp.com/discover/community-conservation/. Accessed $1^{\text {st }}$ March 2019

Higgins-Desbiolles, F. (2008). Justice tourism and globalization. Journal of Sustainable Tourism, 16(3), pp. 345-364.

Higgins-Desbiolles, F. (2006). More than an "industry": The forgotten power of tourism as a social force. Tourism management, 27(6), pp. 1192-1208.

Honey, M. (2011). Travelers' philanthropy handbook. Center for Responsible Travel (CREST). Washington, DC. (Online). Available at: http://www. Travellers philanthropy.org/resources/TPhil\%2oHandbook/Travelers'Philanthropy_ Handbook_by_CREST.pdf. Accessed $19^{\text {th }}$ November, 2018

Kuuder, C.J.W., Bagson, E., and Alangdong, O.I. (2013). Livelihood enhancement through ecotourism: A case of Mognori Ecovillage near Mole National Park, Damango, Ghana. International Journal of Business and Social Science, 4, pp. 132133 .

Kuuder, C.J.W. and Adongo, R. (2012). Pro-poor tourism potentials of Ghana: The contribution of accommodation facilities to poverty alleviation in the Wa Municipality. Ghana Journal of Development Studies, 9(1), pp. 29-41. 
Macy, P. (2011). Unwanted philanthropy: The paint syndrome. Travellers' philanthropy handbook. Washington DC: Centre for Responsible Travel (pp. 177À178).

Mitchell, J. and Ashley, C. (2010). Tourism and Poverty Reduction: Pathways and Prosperity. London: Earthscan.

Mohamadou, S.Y. and Hathie, I. (2015). Institutional forms of philanthropy in West Africa. The State of Philanthropy in Africa. Trust Africa, Dakar. Senegal.

Nelson, F. and Agarwal, A. (2008). Patronage or participation? Community-based natural resource management reform in sub-Saharan Africa. Development and change, 39(4), 557-585.

Nepal Alms Giving Ceremony (2019). All you need to know about almsgiving ceremony in Luang Prabang. (Online). Available at: https://www.tripadvisor.com/ Attraction_Review-g295415-d2229605-Reviews-Alms_Giving_CeremonyLuang_Prabang_Luang_Prabang_Province.html. Accessed $1^{\text {st }}$ February, 2019

Novelli, M. (2015). Are travel philanthropists doing more harm than good? The Conversation, July, 27, 2015.

Porekuu, P. (2010). The Mognori Ecovillage tourism initiative. The Daily Graphic Newspaper, p.19.

Spalding, M. J. (2011). What is successful philanthropy? Travellers' philanthropy handbook Washington, DC: Center for Responsible Travel (pp. 19À24)..

The Business and Financial Times Online. (2018). Northern tourism sector rakes in GH 647,147. (Online). Available at: https://www. myjoyonline.com/business/2018/ february-26th/northern-tourism-sector-rakes-in-gh647147.php. Accessed $4^{\text {th }}$ November, 2018.

Wood, M. (2015). Philanthropic travel: Do good while seeing the world. The wayward post. (Online). Available at: https://thewayforwardpost. com /stories/ 2015/12/17/ philanthropic-travel-do-good-while-seeing-the-world. Accessed $1^{\text {st }}$ December, 2018.

World Tourism Organization [WTO] (2004). Tourism and poverty alleviation, Recommendations for action. Madrid, WTO.

World Tourism Organization [WTO] (1999). Global code of ethics for tourism. (Online). Available at: https://unctad.org/en/docs/tdr1999_en.pdf. Accessed $24^{\text {th }}$ June 2019. 